Published in final edited form as:

J Alzheimers Dis. 2019 ; 69(1): 157-168. doi:10.3233/JAD-180421.

\title{
Neuroprotective Effects of The Amylin Analog, Pramlintide, on AD are associated with Oxidative Stress Regulation Mechanisms
}

\author{
Sarah Patrick ${ }^{1}$, Rachel Corrigan ${ }^{1,{ }^{*}}$, John Grizzani ${ }^{1,{ }^{*}}$, Megan Mey $^{1}$, Jeff Blair ${ }^{1}$, Merce Pallas $^{3}$, \\ Antonio Camins $^{3}$, Hyoung-gon Lee ${ }^{2}$, and Gemma Casadesus ${ }^{1,4}$ \\ ${ }^{1}$ School of Biomedical Sciences, Kent State University, Kent, OH 44124 USA \\ ${ }^{2}$ Department of Biology, the University of Texas San Antonio, San Antonio, TX 78249 USA \\ ${ }^{3}$ Facultat de Farmacia, Universitat de Barcelona, E-08028 Barcelona, Spain \\ ${ }^{4}$ Department of Biological Sciences, Kent State University, Kent OH 44124 USA
}

\section{Abstract}

\begin{abstract}
Administration of the recombinant analog of the pancreatic amyloid amylin, Pramlintide, has shown therapeutic benefits in aging and Alzheimer's disease (AD) models, both on cognition and amyloid-beta $(\mathrm{A} \beta)$ pathology. However, the neuroprotective mechanisms underlying Pramlintide benefits remain unclear. Given the early and critical role of oxidative stress in AD pathogenesis and the known ROS modulating function of amyloids we sought to determine whether Pramlintide's neuroprotective effects involve regulation of oxidative stress mechanisms. To address this we treated APP/PS1 transgenic mice with Pramlintide for 3 months, starting at 5.5 months prior to widespread AD pathology onset, and measured cognition (Morris Water Maze), $\mathrm{AD}$ pathology, and oxidative stress-related markers and enzymes in vivo. In vitro, we determined the ability of Pramlintide to modulate $\mathrm{H}_{2} \mathrm{O}_{2}$-induced oxidative stress levels. Our data show that Pramlintide improved cognitive function, altered amyloid-processing enzymes, reduced plaque burden in the hippocampus, and regulated endogenous antioxidant enzymes (MnSOD and GPx1) and the stress marker HO- 1 in a location specific manner. In vitro, Pramlintide treatment in neuronal models reduced $\mathrm{H}_{2} \mathrm{O}_{2}$-induced endogenous ROS production and lipid peroxidation in a dose-dependent manner. Together, these results indicate that Pramlintide's benefits on cognitive function and pathology may involve antioxidant-like properties of this compound.
\end{abstract}

\section{Keywords}

Amylin; Alzheimer's disease; Oxidative stress; neuroprotection; Pramlintide; metabolism

\section{INTRODUCTION}

Lifestyle factors like obesity and ramifications stemming from obesity, such as metabolic syndrome and the consequential development of Type 2 diabetes mellitus (T2DM), are

Corresponding Author: Gemma Casadesus Smith, Ph. D., Dept. of Biological Sciences, Kent State University, 256 Cunningham Hall, Kent, OH 44240, Tel: 330-672-7894, gcasades@kent.edu.

Authors contributed equally to the manuscript 
associated with the development of sporadic $\mathrm{AD}[1,2]$. T2DM is associated with cognitive decline when compared with age-matched controls [4-7] and is strongly correlated with the development of both MCI and AD, [2,3].

AD and T2DM share multiple common characteristics, such as metabolic dysfunction [8], mitochondrial dysfunction [9], inflammation [10, 11] and, relevant to this work, increased oxidative stress production and impaired oxidative stress defenses [10, 12-14]. Similarly, $\mathrm{T} 2 \mathrm{DM}$ and $\mathrm{AD}$ also each contain a pathological component related to aberrant aggregation of amyloid proteins, namely, $\mathrm{A} \beta$ in $\mathrm{AD}$ and amylin in T2DM [15].

Amylin, or IAPP, is a polypeptide hormone composed of 37 amino acids, synthesized by the $\beta$-cells of the pancreas, is co-released with insulin [16] and crosses the blood brain barrier (BBB) [17]. Amylin also plays a role in glucose homeostasis by preventing the release of glucose from the liver, delaying gastric emptying, and signaling satiety [18]. Similar to A $\beta$ in $\mathrm{AD}$, under normal conditions, amylin exists as a soluble monomer, however it undergoes a conformational change in T2DM which leads to insolubility and aberrant aggregation [19]. This aggregation of amylin eventually leads to the formation of amyloid deposits, which have been proposed, to be the main source of toxicity to $\beta$-cells, leading to their death and consequent decrease of amylin and insulin synthesis later in T2DM [20].

Importantly, a growing number of studies have highlighted a direct relationship between T2DM and AD through the interaction and/or function of these two amyloids, both at a pathological and neuroprotective level. Some work suggests that both amyloids may exert their toxicity to neurons through a shared receptor [21-25] and/or their aggregation serves as a seeding mechanism for the other disease [26, 27]. Conversely, clinical data show a positive correlation between plasma and cerebrospinal fluid amylin levels and cognitive function in T2DM [28], AD, and MCI patients [29, 30]; pre-clinical studies also demonstrated the neuroprotective benefits of amylin and pramlintide (PRAM), a non-aggregating synthetic analogue derived from rat amylin [31]. Evidence suggests that both amylin and PRAM modulate cognition, neuroplasticity, inflammation, [29, 32] and A $\beta$ deposition [33].

Importantly, recent work has shown that while both human amylin and $A \beta_{1-42}$ deregulate identical proteins that lead to increased ROS levels [34]; rat amylin, which does not aggregate [22, 24, 35], does not share the same cytotoxic properties as its human counterpart or $A \beta_{1-42}$ [34]. Thus, these data suggest that loss of native function through amylin aggregation could play a role in both $\mathrm{AD}$ and $\mathrm{T} 2 \mathrm{DM}$ pathogenesis. The above hypothesis is supported by the known antioxidant function of both amylin [36] and $A \beta[37,38]$ in their native conformational states and by the fact that there is increased production of $A \beta$ in $A D$ [39-42]. Additionally, treatment with non-aggregating forms of amylin such as PRAM in T2DM patients [43, 44] and the accelerated aging mouse model (SAMP8) [29], lead to reduced ROS levels.

Thus, given the native role of amyloids in the regulation of oxidative mechanisms and neuronal function as well as the toxic role of oxidative stress in T2DM and AD, we addressed the ability of PRAM to improved cognitive function and reduced pathology in the 
APP/PS1 mouse model. Furthermore, we were particularly interested in determining whether the benefits seen are associated with the anti-oxidative properties of PRAM.

\section{MATERIALS AND METHODS}

\section{In vivo experiments}

ANIMALS-Male and female APP/PS1 mice (B6.Cg-Tg (APPswe, PSEN1dE9)85Dbo/ Mmjax) $(n=30)$ and wild-type (WT) littermates $(n=25)$ were bred in the animal facility of Kent State University for use in this study. Animals were socially caged (2-4 mice per cage) and maintained on a 12/12 light-dark cycle (lights on at 08:00 h, off at 20:00 h) in a temperature-controlled room $\left(72^{\circ} \mathrm{F} \pm 2\right)$. Food and water were available ad libitum. The Institutional Animal Care and Use Committee of Kent State University approved all protocols within this study.

\section{DRUG TREATMENTS}

All mice were aged to 5.5 months prior to the beginning of treatment. APP/PS1 mice were randomly assigned to saline $(\mathrm{N}=15)$ or PRAM treatment $(\mathrm{N}=15)$, while all WT mice received saline ( $\mathrm{N}=25)$. Drugs were delivered through Alzet mini-osmotic pumps (Durect, CA) delivering $0.15 \mu \mathrm{L} / \mathrm{hr}$ steadily for 6 weeks (model 2006) and were replaced every 6 weeks over the course of 18 weeks. PRAM, (Anaspec, CA) was made at a concentration of $421.9 \mu \mathrm{M}$ in sterile, milliQ water and delivered at the desired dose of $6 \mu \mathrm{g} / \mathrm{day}$. This dose was shown to be maximally therapeutic in humans and has also been used in rodent models to improve cognitive function and reduce pathology [29]. A $0.89 \% \mathrm{NaCl}$ saline solution was made in ultrapure MilliQ $\mathrm{H}_{2} \mathrm{O}$ and sterile-filtered. Prior to filling pumps, all solutions were brought to room temperature. All pumps were filled in a sterile hood using sterile techniques and manufacturer's instructions.

\section{SURGICAL PUMP IMPLANTATIONS}

Mice were transferred onto a heating pad and fitted with a nosecone to continue anesthesia with $3 \%$ isoflurane at $1 \mathrm{~L} / \mathrm{min}$. A $1 \mathrm{~cm}$ long incision was made horizontally using dissecting scissors, the pumps were inserted and subcutaneously and the incision was closed using clip wound closures and removed 2 weeks post-surgery (Stoelting, IL). Pumps were changed every 40 days using this same procedure.

\section{BEHAVIORAL TESTING}

Morris Water Maze (MWM) was used to test spatial reference memory using an adapted protocol [45]. Briefly, mice were placed into a MWM pool (Med Associates, VT) with a tank diameter of $100 \mathrm{~cm}$ and were tracked using behavior software (Noldus Ethovision XT 10). The water colored with white tempera non-toxic white paint to conceal the platform (10 $\mathrm{cm}$ diameter) located in the northwest (NW) corner, $5 \mathrm{~mm}$ under the water surface. Temperature was maintained at during testing $22^{\circ} \mathrm{C}$. Mice were placed into the pool surrounded by distal visual cues, at 4 different locations to reduce location biases. Each mouse performed 4 trials per day. Mice that did not reach the platform in 60 seconds were gently guided towards it and all mice were made to remain on the platform for 15 seconds prior to their rescue. Mice were trained for 6 days followed by a probe trial as the last trial 
on day 6 . For the probe trial, the platform was removed and mice were given 60 seconds to explore the maze. The amount of time spent in the target quadrant that had contained the platform (NW) was calculated. A visual platform test was also performed on day 7 to identify potentially blind mice for exclusion in the behavioral task. Animals that floated in 4 consecutive trials during two days of training or were not able to swim for the duration of the trial were also excluded from the study.

\section{TISSUE PREPERATION}

Animals were sacrificed by cervical dislocation and temporal cortex and hippocampi dissected, homogenized in 1X cell lysis buffer (Cell Signaling Technologies, Danver, MA) supplemented with $1 \mathrm{mM} \mathrm{PMSF}$, and stored at $-80^{\circ} \mathrm{C}$ for future use. $\mathrm{A} \beta$ plaque load was visualized in coronal sections from APP/PS1 mice. Briefly, mice were transcardially perfused with $4 \%$ paraformaldehyde made in $1 \mathrm{X}$ PBS before brains were removed. Perfused brains were subsequently for $4 \mathrm{hrs}$ in $4 \%$ paraformaldehyde and then transferred to $30 \%$ sucrose made in 1X PBS until brains sunk for cryoprotection. PFA fixed brains were then frozen in OTC and immersed in 2-Methylbutane (Fisher Scientific, MA) and sliced at $40 \mu \mathrm{M}$ using a cryostat (Leica CM 1950). Sections were stored at $-20^{\circ} \mathrm{C}$ in polyethylene glycol until stained with thioflavin S.

\section{A $\beta$ PLAQUE STAINING AND QUANTIFICATION}

Fixed brain slices were mounted on a slide and immersed in $1 \%$ Thioflavin S solution diluted in milliQ water for 5 minutes. Slides were then moved into $70 \%$ ethanol for 5 minutes. Slides were washed in PBS, then allowed to completely dry and cover slipped on VECTRASHIELD mounting media. Brains were then imaged as 10x z-stacks with $2 \mu \mathrm{M}$ thickness using the Olympus FV500 confocal microscope. For each slice, the entire hippocampus and 3 temporal cortical fields were imaged. Images were stitched together to create a single field and plaques were quantified using Fiji (Image J) to obtain particle count, area, average size, and percent area.

\section{SOLUBLE A $\beta$ MEASUREMENTS}

A $\beta$ (1-40, 1-42, and total) from frozen hippocampal and cortical tissues measured by sandwich ELISA as previously described [46, 47]. Briefly, tissues were extracted first in PBS, then sodium dodecyl sulfate (SDS) and last, formic acid (FA). Antibodies Ab42.5 (human sequence $A \beta$ (1-16) for $A \beta$ 1-40 capture, and 2.1.3 (end specific for $A \beta$ 1-42) were used in each brain fraction (PBS, SDS, and FA).

\section{WESTERN BLOTTING}

Tris-acrylamide gels were made at $4 \%$ for stacking gel and 10\% for resolving gel. $15 \mu \mathrm{g}$ of protein was separated using and SDS-PAGE Bio-Rad mini protein system (Bio-Rad, CA). Blots were blocked in $10 \%$ nonfat milk for 1 hour at room temperature. Primary antibodies (HO-1 (Rabbit, 1:2000, abcam), Glutathione Peroxidase (Rabbit, 1:1000, abcam), BACE-1 (Rabbit, 1:1000, abcam), ADAM10 (Rabbit, 1:1000, abcam) and GAPDH (mouse, 1:2000, sigma-aldrich) were incubated overnight at $4^{\circ} \mathrm{C}$ in $1 \%$ milk made in TBST. Secondary antibodies (1:1000) Ms IgG HRP-conjugated or Rb IgG HRP-conjugated (Cell Signaling 
Technologies, Danvers, MA) were incubated for 1 hour at room temperature in $1 \%$ milk made in TBST. Proteins were visualized using ECL (Millipore) and a chemiluminescent developer (Syngene Pxi 6 Touch). Images were quantified using Image J software.

\section{IN VITRO EXPERIMENTS}

SH-SY5Y (ATCC ${ }^{\circledR}$ CRL-2266 ${ }^{\mathrm{TM}}$, Manassas, VA), where purchased and differentiated with retinoic acid following previous protocols [48, 49]. Cells used where all treated within 4-7 passages. Cells were plated accordingly for in vitro assays per manufacturer's instructions. Doses were based on preliminary study data, studies showing antioxidant function at these doses $[36,50,51]$ and/or and kept below $10 \mu \mathrm{M}$ given recent data suggesting the ability of amylin to activate downstream TRPV4 receptors and induce high levels of intracellular $\mathrm{Ca}+$ + and cytotoxicity [50, 51]. All assays were conducted in triplicate and replicated at least twice in two independent experiments.

\section{DCF ASSAY}

The dichlorofluorescein (DCF) assay was performed using differentiated SH-SY5Y as described in [52]. Following standard retinoic acid differentiation media was changed to serum/phenol-free Optimem (Life technologies) for 16-18 hours. Treatments included: no treatment, $\mathrm{DCF}$ alone, $\mathrm{DCF}+\mathrm{FeSO} 4, \mathrm{DCF}+\mathrm{FeSO} 4+\mathrm{H}_{2} \mathrm{O}_{2}$ and $\mathrm{PRAM}+\mathrm{DCF}+\mathrm{FeSO} 4+$ $\mathrm{H}_{2} \mathrm{O}_{2}$. Four PRAM doses (1nM, 10nM, 100nM, 250nM) were applied 24hrs prior to exposure of an oxidative insult (5 mM H2O2) as described in [36] showing DCF changes by amylin in $\beta$-cells of the pancreas. On the experimental day, media was changed, PRAM was re-added to each well for 1 hour to ensure stable levels of PRAM prior to the oxidative insult. Cells were rinsed twice and $20 \mu \mathrm{M}$ H2DCF-DA in Optimem was added to cells for 1 hour at $37^{\circ} \mathrm{C}$. Cells were washed twice again and $\mathrm{H}_{2} \mathrm{O}_{2}$ (Acros Organics, $\mathrm{NJ}$ ) at final concentration of $5 \mathrm{mM}$ was added to all wells in addition to $8 \mu \mathrm{M}$ FeSO4. This solution was allowed to incubate with cells for 30 minutes. The florescence was read at $485 \mathrm{~nm}$ excitation wavelength and $530 \mathrm{~nm}$ emission wavelength using a microplate reader (Molecular Devices) at $37^{\circ} \mathrm{C}$. Levels of florescence were expressed relative to untreated controls.

\section{TBARS ASSAY}

SH-SY5Y cells were plated in 96 well plates $\left(5 \times 10^{4}\right)$ and differentiated following standard retinoic acid differentiation. PRAM doses $(500 \mathrm{nM}, 1000 \mathrm{nM}, 5000 \mathrm{nM})$ and incubation times were chosen based and previous work identifying similar antioxidant effects of amylin in pancreatic cell cultures [36]. After 1 hour of PRAM incubation, $5 \mathrm{mM} \mathrm{H}_{2} \mathrm{O}_{2}$ was added into the wells and allowed to incubate for 30 minutes, supernatant was then collected for TBARS assay, which was carried out using manufacturer's instructions (R\&D Systems, MN). MDA levels were measured colorimetrically through its reaction with thiobarabituric acid (TBA) at an absorbance of $535 \mathrm{~nm}$ using a microplate reader (Molecular Devices) for all treatment groups. Data is portrayed as MDA \% change (TBARS \% change).

\section{STATISTICAL ANALYSIS}

All in vivo testing and analyses were carried out by an investigator blind to treatment, cell culture data was analyzed blind to treatment. Experiments were powered based on previous 
published data in the field and experiments in the laboratory at was set at $80 \%$. Outliers were detected using the Grubb's test and excluded from the data analysis if significant. Normality and homogeneity of variance were verified to ensure normality prior to parametric statistical analyses. Statistical significance was determined using a One-Way ANOVA with Tukey's post hoc analysis for any experiments with more than 2 groups. Independent samples T-test were used to statistically analyze differences between treated and untreated transgenic mice. A p $<0.05$ was deemed as statistically significant. Data is expressed as mean and standard error mean (mean \pm SEM). Sex differences were determined for variables where power was sufficient. There were no sex differences for cognitive function. Due to increased death of female APP/PS1 (of all groups) the female $\mathrm{n}$ number was too small to identify relevant sex differences for biochemical measurements. Based on this analyses all statistical analyses were carried out grouping sexes.

\section{RESULTS \\ IN VIVO/EX-VIVO STUDIES}

PRAMLATIDE TREATMENT RESCUSES SPATIAL LEARNING AND MEMORYMWM was used to determine differences in spatial hippocampal memory between saline treated WT, saline treated APP/PS1 (Tg+SAL), and PRAM treated APP/PS1 (Tg+PRAM) mice. A One-Way ANOVA analysis identified a significant difference between subjects group $\left(\mathrm{F}_{1,2}=7.806 ; \mathrm{p}=0.002\right)$ and a within subject significant difference across days $\left(\mathrm{F}_{1,5}\right.$ $=18.574 ; \mathrm{p}=0.0001)$. However, there were not statistical differences in the day*group interaction $\left(\mathrm{F}_{1,5}=1.523 ; \mathrm{p}=0.136\right)$. These data indicate that while there was an overall group difference in performance across groups for the task, the rate of learning across days was not different between groups. Tukey's post-hoc multiple comparisons analysis demonstrated that $\mathrm{Tg}+\mathrm{SAL}$ mice performed significantly worse compared to WT animals ( $\mathrm{p}$ $=0.002)$ and Tg+PRAM animals $(\mathrm{p}=0.026)$. There were no statistically significant differences between WT and Tg+PRAM treated animals $(\mathrm{p}=0.964)$, suggesting that drug treatment rescued performance in the MWM to WT levels (Figure 2A).

Within subjects comparisons across days of training revealed significant group differences for Days $5\left(\mathrm{~F}_{1,2}=9.461 ; \mathrm{p}=0.001\right)$ and $6\left(\mathrm{~F}_{1,2}=6.047 ; \mathrm{p}=0.006\right)$ of training. Tukey's post-hoc analyses for Day 5 of training revealed statistically significant differences between $\mathrm{Tg}+\mathrm{SAL}$ and Tg+PRAM $(\mathrm{p}=0.015)$ and Tg+SAL vs WT control animals $(\mathrm{p}=0.001)$, with $\mathrm{Tg}+\mathrm{SAL}$ mice showing cognitive deficits. There was no statistical difference between $\mathrm{Tg}$ +PRAM and WT ( $\mathrm{p}=0.935)$. Tukey's post-hoc analyses for Day 6 of training revealed similar statistically significant difference between $\mathrm{Tg}+\mathrm{SAL}$ and Tg+PRAM $(\mathrm{p}=0.035)$, as well as between Tg+SAL and WT ( $\mathrm{p}=0.005)$, again indicating a cognitive deficit. Tg +PRAM and WT mice performed similarly $(\mathrm{p}=0.998)($ Figure 2A).

In order to determine differences in retention and spatial strategy, a One-Way ANOVA was used to identify differences in the probe trial. An overall significant difference between groups was found $\left(\mathrm{F}_{1,2}=7.376 ; \mathrm{p}=0.002\right)$. Tukey's post-hoc analysis revealed a statistically significant difference between WT and Tg+SAL $(p=0.002)$, and a nonsignificant trend between Tg+PRAM and Tg+SAL $(p=0.08)$. There were no statistically significant differences between Tg+PRAM and WT control groups $(\mathrm{p}=0.695)$, as shown in 
Figure 2B. This data indicate that PRAM was partially able to rescue spatial memory retention.

\section{PRAMLATIDE TREATMENT REDUCES SOLUBLE A $\beta$ \& PLAQUES IN THE HIPPOCAMPUS}

Plaque load: Independent Samples T-test comparisons between PRAM-treated and nontreated APP/PS1 mice revealed that, in the hippocampus, Tg+PRAM mice had a significantly decreased percent area plaque coverage $\left(\mathrm{t}_{1,9}=-2.818, \mathrm{p}=0.022\right)$ and plaque number $\left(\mathrm{t}_{1,9}=-2.872, \mathrm{p}=0.024\right)$ compared to $\mathrm{Tg}+\mathrm{SAL}$ mice (Figure $\left.3 \mathrm{~A} \& \mathrm{~B}\right)$. In the cortex, there were no significant differences in plaque count or percent area with plaques between treatments. There were also no significant differences between groups for average plaque size either in the cortex or hippocampus.

Soluble \& Insoluble A $\beta$ fractions: Independent Samples T-test was also used to determine differences in soluble (PBS), membrane bound (SDS) and insoluble (FA) fractions of A $\beta 1-$ 40 and 1-42 in the in the hippocampus and cortex of PRAM-treated and saline-treated animals (Figure 3C). In the hippocampus, Tg+PRAM mice had significantly lower levels of insoluble (FA) $\mathrm{A} \beta_{1-40}\left(\mathrm{t}_{1,6}=-2.051, \mathrm{p}=0.046\right)$ and $\mathrm{A} \beta_{1-42}\left(\mathrm{t}_{1,6}=-2.631, \mathrm{p}=0.039\right)$ compared to $\mathrm{Tg}+\mathrm{SAL}$ animals. A trend toward lower soluble (PBS) $\mathrm{A} \beta_{1-42}$ in the Tg+PRAM compared to $\mathrm{Tg}+\mathrm{SAL}$ treated mice $\left(\mathrm{t}_{1,6}=-2.061, \mathrm{p}=0.085\right)$ was also identified (Figure $3 \mathrm{C})$. In the cortex (data not shown), there were no significant differences between groups other than reduced levels of membrane bound (SDS) $A \beta_{1-40}\left(t_{1,6}=2.9220, p=0.027\right)$ in the $\mathrm{Tg}+\mathrm{SAL}$ group when compared to the $\mathrm{Tg}+\mathrm{PRAM}$ group. A non-significant trend toward lower insoluble (FA) $\mathrm{A} \beta_{1-42}$ in the PRAM-treated compared to saline-treated mice was also observed $\left(\mathrm{t}_{1,6}=-2.064, \mathrm{p}=0.083\right)$.

\section{PRAMLATIDE TREATMENT ALTERS APP PROCESSING \& OXIDATIVE STRESS MARKERS-Independent Samples T-test analysis demonstrated a statistically significant increase in a-secretase (ADAM 10) expression in the cortex of Tg+PRAM vs Tg+SAL mice $\left(\mathrm{t}_{1,9}=4.277, \mathrm{p}=0.022\right)$ and hippocampus $\left(\mathrm{t}_{1,9}=5.032, \mathrm{p}=0.001\right)$. Interestingly, $\beta$-secretase expression (BACE1) was significantly increased by PRAM treatment in the hippocampus $\left(\mathrm{t}_{1,9}=3.413, \mathrm{p}=0.008\right)$ but not in the cortex of APP/PS1 mice ( $\left.\mathrm{p}=0.759\right)$ (Figure 4).}

Western blots for oxidative-stress related markers such as heme-oxygenase-1 (HO-1), glutathione peroxidase (GPx), and manganese superoxide dismutase (MnSOD) expression in the cortex and hippocampus of $\mathrm{Tg}+\mathrm{SAL}$ and $\mathrm{Tg}+\mathrm{PRAM}$ mice revealed region-specific differences. Independent groups T-test analyses identified a significant decrease in HO-1 expression in the cortex of Tg+PRAM treated compared to TG+SAL mice $\left(\mathrm{t}_{1,9}=-3.407 ; \mathrm{p}\right.$ $<0.01$ ) while there was a significant increase in HO-1 expression in the hippocampus $\left(\mathrm{t}_{1,9}=\right.$ 2.310; $\mathrm{p}=0.046)$. GPx expression was significantly increased in the hippocampi of $\mathrm{Tg}$ + PRAM animals compared to controls $\left(\mathrm{t}_{1,9}=3.658 ; \mathrm{p}=0.008\right)$ but not in the cortex, despite a strong trend $(\mathrm{p}=0.07)$. Lastly, significant increases in MnSOD expression in the $\mathrm{Tg}$ + PRAM mice were observed when compared to $\mathrm{Tg}+\mathrm{SAL}$ in the hippocampus $\left(\mathrm{T}_{1,9}=2.93\right.$; $\mathrm{p}=0.017)$ but not in the cortex $(\mathrm{p}=0.58)($ Figure 4$)$. 


\section{IN VITRO STUDIES}

\section{PRAM DECREASES $\mathrm{H}_{\mathbf{2}} \mathrm{O}_{\mathbf{2}}$-INDUCED INTRACELLULAR ROS PRODUCTION \&} LIPID PEROXIDATION-The ability of PRAM to regulate $\mathrm{H}_{2} \mathrm{O}_{2}$-induced oxidative stress parameters was evaluated through DCF and TBARS assays in differentiated SH-5Y5Y cells. DCF assays were statistically analyzed via One-way ANOVA. Analyses revealed a statistically significant difference between groups in the DCF assay $\left(\mathrm{F}_{1,5}=7.638 ; \mathrm{p}\right.$ 0.001). Post-hoc analysis identified a significant increase in intracellular ROS production by $\mathrm{H}_{2} \mathrm{O}_{2}$ administration compared to untreated control cells ( $\mathrm{p}<0.001$ ) and control and $\mathrm{H}_{2} \mathrm{O}_{2}+1 \mathrm{nM}(\mathrm{p}=0.023)$ and $\mathrm{H}_{2} \mathrm{O}_{2}+10 \mathrm{nM}$ PRAM doses ( $\left.\mathrm{p}=0.034\right)$. Importantly, preincubation with PRAM at $100 \mathrm{nM}(\mathrm{p}<0.0001)$ and $250 \mathrm{nM}(\mathrm{p}<0.0001)$ was able to significantly reduce DCF fluorescence compared cells treated with $\mathrm{H}_{2} \mathrm{O}_{2}$ alone (Figure 5A).

Statistical analysis of TBARS assays in differentiated SHSY5Y cells (Figure 5B) revealed a significant difference between groups $\left(\mathrm{F}_{1,4}=13.722 ; \mathrm{p}<0.001\right)$ via one-way ANOVA. Tukey's post-hoc analysis indicated a significant increase in lipid peroxidation between all $\mathrm{H}_{2} \mathrm{O}_{2}$ treated groups (with and without PRAM treatment) compared to untreated controls $(\mathrm{p}<0.01-0.001)$. Significant decreases in MDA concentration were seen in the $500 \mathrm{nM}$ $\mathrm{PRAM}+\mathrm{H}_{2} \mathrm{O}_{2}(\mathrm{p}=0.007)$ and 5000nM PRAM $+\mathrm{H}_{2} \mathrm{O}_{2}(\mathrm{p}=0.018)$ treatments when compared to $\mathrm{H}_{2} \mathrm{O}_{2}$ alone. There were no significant differences across PRAM dosages.

\section{DISCUSSION}

Here we show that continuous and chronic administration of PRAM ameliorates cognitive deficits in MWM test. These findings are in accordance with an independent study showing the ability of intraperitoneal (i.p.) and/or ICV delivered amylin or PRAM to improve function in other AD mouse models [33]. Importantly, our work was carried out using a dose within the therapeutic range administered to humans, therefore highlighting its translational therapeutic applicability.

Notably, treatment with PRAM reduced A $\beta$ plaque burden in APP/PS1 mice. However, unlike previous work [33], this study revealed a reduction in $A \beta$ plaque burden in the hippocampus but not the cortex. These changes were also reflected in the soluble fraction measurements, where hippocampal levels of insoluble (FA) $A \beta_{1-40}$ and/or $A \beta_{1-42}$ were more effectively reduced by our treatment than in the cortex. Also of note, a non-significant trend was observed for the soluble (PBS) $A \beta_{1-42}$ fraction in the hippocampus. Together, these data suggest that PRAM may increase the clearance of $A \beta$ in the brain, thus reducing plaque formation, an assertion supported by previous reports demonstrating a dosedependent increase in $A \beta_{1-42}$ in efflux into the periphery [33].

Differences between our study and others [33] may stem from treatment protocol differences (i.p. vs continuous s.c. infusion), length of treatment, peptide used (amylin versus PRAM), transgene, or staining methods. However, a potential contributor to these differences may also be the timing of treatment initiation in relation to the temporal pattern of plaque deposition and regional expression across the different mouse models. In our model, plaque deposition begins 4.5 months of age in the cortex, and progresses to the hippocampus at 6.5 months of age [53]. As our treatment began when the mouse was aged at 5.5 months, when 
cortical plaque deposition has been established, this may indicate that PRAM can prevent plaque pathology but not modify existing plaques. This hypothesis is supported in the work using Tg2576 models showing widespread reduction in pathology [33] at relevant ages for that mouse. In Tg2576 mice initial plaque deposition occurs at 10 months with substantial plaque burden at 12 months [54]. Therefore, the initiation of treatment at 9 months of age would occur prior to initial plaque deposition and yield more widespread reductions in pathology. This is further validated by our $\mathrm{A} \beta$ fraction measurements demonstrating more efficient reductions of $A \beta_{1-42}$ in the hippocampus versus the cortex, where only a trend was observed for FA soluble (fibrilized) A $\beta$ 1-42.

To address potential effects of PRAM on amyloid precursor protein (APP) processing we determined expression levels of amyloidogenic $\beta$-secretase (BACE1) and nonamyloidogenic $a$-secretase (ADAM-10) enzymes in cortex and hippocampi of our APP/PS1 animals. Interestingly, PRAM increased both BACE1 and ADAM-10 in the hippocampus, where both soluble $A \beta$ fractions and plaque load were significantly reduced. Conversely, ADAM-10 but not BACE1 was significantly increased in the cortex, yet we saw no significant difference in plaque load or soluble/insoluble A $\beta$ levels. Previous work has demonstrated that amylin but not PRAM has inhibitory BACE1 properties, however, to our knowledge there are no reports of upregulation of these enzymes by either PRAM or amylin treatment. While the significance of these data is unclear, it is possible that PRAM drives a generalized enzymatic response, perhaps, associated with efflux of soluble $A \beta$ species into the periphery regions but only in areas that are actively undergoing $A \beta$ deposition. This aspect has been previously associated with administration of PRAM and amylin [33]. Certainly, our data do not provide a clear relationship between APP cleavage enzyme expression and $A \beta$ deposition in relation to PRAM treatment. However, our data do suggest that PRAM treatment may have a more robust effect on regulating $\alpha$-secretase expression that $\beta$-secretase, given that both cortex and hippocampus shows increases in ADAM-10 expression. These data potentially highlight a novel role of PRAM through increasing $\alpha$ secretase activity and cleavage of APP toward the non-amyloidogenic pathway. Time course studies starting therapy at different ages will help clarify and further validate the precise nature of interactions between amyloid-beta processing, $A \beta$ deposition and the role of PRAM and timing of treatment onset in these processes.

Oxidative stress has been shown to be a major component AD [55-58] and may even precede AD development. [41,56]. Therefore, an imbalance between increased ROS and decreased antioxidant defenses may be a fundamental event in AD development [59-61]. Critically, it has been established that insulin resistance and diabetes lead to increases in oxidative stress directly [62-65] or indirectly through increasing inflammation [66, 67]. Incidentally, PRAM administration in T2DM patients reduces the levels of serum markers of oxidative stress $[43,44]$ and can also form a complex with $\mathrm{Cu}$ (II) [68] that can mimics antioxidant enzymes to reduce ROS $[69,70]$. Importantly, previous work has shown the ability of PRAM to reduce lipid peroxidation damage and inflammatory markers and stress related responses HO-1 in a mouse model of accelerated aging [29].

HO-1 is an inducible enzyme that degrades the pro-oxidant heme, leading to the formation of the powerful antioxidants biliverdin and bilirubin [71, 72]. It is upregulated by numerous 
factors, including oxidative stress [73, 74], and is upregulated in $\mathrm{AD}[75,76]$. On the other hand, HO-1 has also been shown to protect against $A \beta$ toxicity in the hippocampus [75] and A $\beta$-related mitochondrial dysfunction [77]. Our data shows that while expression of HO-1 was reduced by PRAM treatment in the cortex, the expression of HO-1 was significantly increased by PRAM in the hippocampus. These seemingly paradoxical effects of PRAM treatment in different brain regions remains puzzling, however, a plausible explanation may lie in the differential make-up of the cortex versus the hippocampus, the timing of and plateau of pathology, and the ability of PRAM to regulate inflammatory states [29, 32, 78]. As discussed above, in our AD model, the onset of treatment would coincide with initial plaque deposition in the hippocampus but not the cortex. Therefore, PRAM ability to reduce HO-1 in areas were plaque formation has plateaued could be reflective of its general antiinflammatory function while the activation of HO-1 in the hippocampus could be reflective of a more acute inflammatory response pattern that can foster clearance of soluble $A \beta$ before it has a chance to fibrillize [79]. Future studies will need to more closely identify the role of amylin regulation inflammatory aspects within an AD milieu to fully clarify these data.

Our work also shows that the antioxidant enzymes MnSOD and GPx were significantly increased in hippocampus, but not cortex of PRAM treated mice when compared to saline treated APP/PS1 mice. As discussed previously, patients with MCI and AD exhibit decreased total antioxidant capability [60], and increased production of $\mathrm{O}_{2 .-}$ [80] which stimulates the amyloidogenic pathway [81]. With the substantial upregulation of MnSOD to combat this free radical, this may be a potential mechanism by which PRAM exerts its benefits both at a functional and pathology level. Furthermore, the significant increases of GPx in hippocampus by PRAM treatment further bolsters the antioxidant defenses against ROS.

To delve deeper into identifying whether antioxidant regulation may underlie the neuroprotective benefits of PRAM we carried out a variety of in vitro assays, which showed that PRAM treatment reduced intracellular ROS production (DCF assay) and lipid peroxidation (TBARS) in the response of an oxidative insult $\left(\mathrm{H}_{2} \mathrm{O}_{2}\right)$. Effectiveness of PRAM on lipid peroxidation was seen at higher doses than its ability to quench intracellular ROS production. This is likely due to the fact that for the TBARS assay incubation was carried out for $1 \mathrm{hr}$ versus $24 \mathrm{hrs}$ for the DCF assay. While future studies should replicate the time-course and doses used in the DCF assay for lipid peroxidation measurements, these findings support previous in vivo data demonstrating the ability of PRAM to reduce 4-HNE levels [29]. Intracellular ROS production and lipid peroxidation could be reduced through the ability of PRAM to increase endogenous antioxidant enzymes as shown in in vivo work. An additional intriguing possibility, based on work in pancreatic cell lines [36], is that PRAM may itself become an activated antioxidant after forming complexes with $\mathrm{Cu}$ (II). This would also explain the decreases in ROS and, to a greater extent, lipid peroxidation. These latter aspects should be explored in future studies.

Two aspects that remain unanswered by this work but that should form the basis of future studies are the ability of amylin to regulate mitochondrial health and the specific mechanism of action of amylin. In the present study, we found increases in GPx, known to protect mitochondria [82] and MnSOD (located within the mitochondria [83]) in the hippocampi of 
PRAM treated mice. Mitochondrial dysfunction precedes the increase in ROS and oxidative damage [84]. Thus, a possibility to explore is that PRAM may act directly on the mitochondria health to yield its benefits. In support of this hypothesis, recent work demonstrates that PRAM treatment reduced intracellular of calcium release, rescued mitochondrial membrane potential loss, inhibited the mitochondrial mediated apoptosis pathways, and increased ATP production under both hypoxic and normoxic conditions [50]. Additionally, it is unclear whether PRAM treatment in our in vivo study is providing benefits by directly through one or a number of its native receptors or whether its effects are driven through its ability to regulate insulin sensitivity peripherally and improve general metabolic tone (which also could reduce pathology and ROS) and should also be clarified. This is particularly relevant given the conflicting data showing that both inhibition of the receptor [21-25] and its activation through amylin or PRAM [29,33] produce benefits in AD models. A recent study showing that while $A \beta$ and human amylin disrupt LTP, pretreatment with PRAM can rescue this decrease to wild-type levels in a mouse model of AD [85].

\section{ACKNOWLEDGEMENTS/CONFLICTS OF INTEREST DISCLOSURE:}

This work was funded by the Alzheimer's Association (NPSPAD 247219) and NIA (1R15AG050292-01A1). The P.I. or co-authors have no conflicts of interest. We thank Dr. P. Murphy and L. Head for carrying out the soluble amyloid-beta measurements for this work.

\section{REFERENCES}

[1]. Butterfield DA, Di Domenico F, Barone E (2014) Elevated risk of type 2 diabetes for development of Alzheimer disease: a key role for oxidative stress in brain. Biochim Biophys Acta 1842, 16931706. [PubMed: 24949886]

[2]. Cheng G, Huang C, Deng H, Wang H (2012) Diabetes as a risk factor for dementia and mild cognitive impairment: a meta-analysis of longitudinal studies. Intern Med J 42, 484-491. [PubMed: 22372522]

[3]. Li X, Song D, Leng SX (2015) Link between type 2 diabetes and Alzheimer's disease: from epidemiology to mechanism and treatment. Clin Interv Aging 10, 549-560. [PubMed: 25792818]

[4]. Brands AM, Van den Berg E, Manschot SM, Biessels GJ, Kappelle LJ, De Haan EH, Kessels RP (2007) A detailed profile of cognitive dysfunction and its relation to psychological distress in patients with type 2 diabetes mellitus. J Int Neuropsychol Soc 13, 288-297. [PubMed: 17286886]

[5]. Awad N, Gagnon M, Messier C (2004) The relationship between impaired glucose tolerance, type 2 diabetes, and cognitive function. J Clin Exp Neuropsychol 26, 1044-1080. [PubMed: 15590460]

[6]. de la Monte SM (2014) Type 3 diabetes is sporadic Alzheimers disease: mini-review. Eur Neuropsychopharmacol 24, 1954-1960. [PubMed: 25088942]

[7]. Kandimalla R, Thirumala V, Reddy PH (2017) Is Alzheimer's disease a Type 3 Diabetes? A critical appraisal. Biochim Biophys Acta 1863, 1078-1089.

[8]. Walker JM, Harrison FE (2015) Shared Neuropathological Characteristics of Obesity, Type 2 Diabetes and Alzheimer's Disease: Impacts on Cognitive Decline. Nutrients 7, 7332-7357. [PubMed: 26340637]

[9]. Petersen KF, Dufour S, Befroy D, Garcia R, Shulman GI (2004) Impaired mitochondrial activity in the insulin-resistant offspring of patients with type 2 diabetes. N Engl J Med 350, 664-671. [PubMed: 14960743]

[10]. Nowotny K, Jung T, Hohn A, Weber D, Grune T (2015) Advanced glycation end products and oxidative stress in type 2 diabetes mellitus. Biomolecules 5, 194-222. [PubMed: 25786107] 
[11]. Yang Y, Song W (2013) Molecular links between Alzheimer's disease and diabetes mellitus. Neuroscience 250, 140-150. [PubMed: 23867771]

[12]. Evans JL, Maddux BA, Goldfine ID (2005) The molecular basis for oxidative stress-induced insulin resistance. Antioxid Redox Signal 7, 1040-1052. [PubMed: 15998259]

[13]. Asmat U, Abad K, Ismail K (2016) Diabetes mellitus and oxidative stress-A concise review. Saudi Pharmaceutical Journal 24, 547-553. [PubMed: 27752226]

[14]. Trivedi S, Lal N, Mahdi AA, Mittal M, Singh B, Pandey S (2014) Evaluation of antioxidant enzymes activity and malondialdehyde levels in patients with chronic periodontitis and diabetes mellitus. J Periodontol 85, 713-720. [PubMed: 23895253]

[15]. Haque R, Nazir A (2014) Insulin-degrading enzyme: a link between Alzheimer's and type 2 diabetes mellitus. CNS Neurol Disord Drug Targets 13, 259-264. [PubMed: 24059320]

[16]. Banks WA, Kastin AJ (1998) Differential permeability of the blood-brain barrier to two pancreatic peptides: insulin and amylin. Peptides 19, 883-889. [PubMed: 9663454]

[17]. Qiu WQ, Zhu H (2014) Amylin and its analogs: a friend or foe for the treatment of Alzheimer's disease? Front Aging Neurosci 6, 186. [PubMed: 25120481]

[18]. Martin C (2006) The physiology of amylin and insulin: maintaining the balance between glucose secretion and glucose uptake. Diabetes Educ 32 Suppl 3, 101s-104s. [PubMed: 16751350]

[19]. Jaikaran ET, Clark A (2001) Islet amyloid and type 2 diabetes: from molecular misfolding to islet pathophysiology. Biochim Biophys Acta 1537, 179-203. [PubMed: 11731221]

[20]. Pillay K, Govender P (2013) Amylin uncovered: a review on the polypeptide responsible for type II diabetes. Biomed Res Int 2013, 826706. [PubMed: 23607096]

[21]. Jhamandas JH, Li Z, Westaway D, Yang J, Jassar S, MacTavish D (2011) Actions of betaamyloid protein on human neurons are expressed through the amylin receptor. Am J Pathol 178, 140-149. [PubMed: 21224052]

[22]. Jhamandas JH, MacTavish D (2004) Antagonist of the amylin receptor blocks beta-amyloid toxicity in rat cholinergic basal forebrain neurons. J Neurosci 24, 5579-5584. [PubMed: 15201330]

[23]. Fu W, Ruangkittisakul A, MacTavish D, Shi JY, Ballanyi K, Jhamandas JH (2012) Amyloid beta (Abeta) peptide directly activates amylin-3 receptor subtype by triggering multiple intracellular signaling pathways. J Biol Chem 287, 18820-18830. [PubMed: 22500019]

[24]. Lim YA, Ittner LM, Lim YL, Gotz J (2008) Human but not rat amylin shares neurotoxic properties with Abeta42 in long-term hippocampal and cortical cultures. FEBS Lett 582, 2188 2194. [PubMed: 18486611]

[25]. Soudy R, Patel A, Fu W, Kaur K, MacTavish D, Westaway D, Davey R, Zajac J, Jhamandas J (2017) Cyclic AC253, a novel amylin receptor antagonist, improves cognitive deficits in a mouse model of Alzheimer's disease. Alzheimers Dement (N Y) 3, 44-56. [PubMed: 29067318]

[26]. Miklossy J, Qing H, Radenovic A, Kis A, Vileno B, Laszlo F, Miller L, Martins RN, Waeber G, Mooser V, Bosman F, Khalili K, Darbinian N, McGeer PL (2010) Beta amyloid and hyperphosphorylated tau deposits in the pancreas in type 2 diabetes. Neurobiol Aging 31, 15031515. [PubMed: 18950899]

[27]. Bharadwaj P, Wijesekara N, Liyanapathirana M, Newsholme P, Ittner L, Fraser P, Verdile G (2017) The Link between Type 2 Diabetes and Neurodegeneration: Roles for Amyloid-beta, Amylin, and Tau Proteins. J Alzheimers Dis 59, 421-432. [PubMed: 28269785]

[28]. Qiu WQ, Li H, Zhu H, Scott T, Mwamburi M, Rosenberg I, Rosenzweig J (2014) Plasma Amylin and Cognition in Diabetes in the Absence and the Presence of Insulin Treatment. J Diabetes Metab 5.

[29]. Adler BL, Yarchoan M, Hwang HM, Louneva N, Blair JA, Palm R, Smith MA, Lee HG, Arnold SE, Casadesus G (2014) Neuroprotective effects of the amylin analogue pramlintide on Alzheimer's disease pathogenesis and cognition. Neurobiol Aging 35, 793-801. [PubMed: 24239383]

[30]. Roostaei T, Nazeri A, Felsky D, De Jager PL, Schneider JA, Pollock BG, Bennett DA, Voineskos AN (2017) Genome-wide interaction study of brain beta-amyloid burden and cognitive impairment in Alzheimer's disease. Mol Psychiatry 22, 287-295. [PubMed: 27021820] 
[31]. Bower RL, Hay DL (2016) Amylin structure-function relationships and receptor pharmacology: implications for amylin mimetic drug development. British Journal of Pharmacology 173, 18831898. [PubMed: 27061187]

[32]. Wang E, Zhu H, Wang X, Gower AC, Wallack M, Blusztajn JK, Kowall N, Qiu WQ (2017) Amylin Treatment Reduces Neuroinflammation and Ameliorates Abnormal Patterns of Gene Expression in the Cerebral Cortex of an Alzheimer's Disease Mouse Model. J Alzheimers Dis 56, 47-61. [PubMed: 27911303]

[33]. Zhu H, Wang X, Wallack M, Li H, Carreras I, Dedeoglu A, Hur JY, Zheng H, Li H, Fine R, Mwamburi M, Sun X, Kowall N, Stern RA, Qiu WQ (2015) Intraperitoneal injection of the pancreatic peptide amylin potently reduces behavioral impairment and brain amyloid pathology in murine models of Alzheimer's disease. Mol Psychiatry 20, 252-262. [PubMed: 24614496]

[34]. Lim YA, Rhein V, Baysang G, Meier F, Poljak A, Raftery MJ, Guilhaus M, Ittner LM, Eckert A, Gotz J (2010) Abeta and human amylin share a common toxicity pathway via mitochondrial dysfunction. Proteomics 10, 1621-1633. [PubMed: 20186753]

[35]. May PC, Boggs LN, Fuson KS (1993) Neurotoxicity of human amylin in rat primary hippocampal cultures: similarity to Alzheimer's disease amyloid-beta neurotoxicity. J Neurochem 61, 2330-2333. [PubMed: 8245987]

[36]. Lee EC, Ha E, Singh S, Legesse L, Ahmad S, Karnaukhova E, Donaldson RP, Jeremic AM (2013) Copper(II)-human amylin complex protects pancreatic cells from amylin toxicity. Phys Chem Chem Phys 15, 12558-12571. [PubMed: 23793354]

[37]. Atwood CS, Obrenovich ME, Liu T, Chan H, Perry G, Smith MA, Martins RN (2003) Amyloidbeta: a chameleon walking in two worlds: a review of the trophic and toxic properties of amyloidbeta. Brain Res Brain Res Rev 43, 1-16. [PubMed: 14499458]

[38]. Zou K, Gong JS, Yanagisawa K, Michikawa M (2002) A novel function of monomeric amyloid beta-protein serving as an antioxidant molecule against metal-induced oxidative damage. J Neurosci 22, 4833-4841. [PubMed: 12077180]

[39]. Gibson GE, Zhang H, Sheu KR, Park LC (2000) Differential alterations in antioxidant capacity in cells from Alzheimer patients. Biochim Biophys Acta 1502, 319-329. [PubMed: 11068175]

[40]. Nunomura A, Perry G, Pappolla MA, Friedland RP, Hirai K, Chiba S, Smith MA (2000) Neuronal oxidative stress precedes amyloid-beta deposition in Down syndrome. J Neuropathol Exp Neurol 59, 1011-1017. [PubMed: 11089579]

[41]. Nunomura A, Perry G, Aliev G, Hirai K, Takeda A, Balraj EK, Jones PK, Ghanbari H, Wataya T, Shimohama S, Chiba S, Atwood CS, Petersen RB, Smith MA (2001) Oxidative damage is the earliest event in Alzheimer disease. J Neuropathol Exp Neurol 60, 759-767. [PubMed: 11487050]

[42]. Cuajungco MP, Goldstein LE, Nunomura A, Smith MA, Lim JT, Atwood CS, Huang X, Farrag YW, Perry G, Bush AI (2000) Evidence that the beta-amyloid plaques of Alzheimer's disease represent the redox-silencing and entombment of abeta by zinc. J Biol Chem 275, 19439-19442. [PubMed: 10801774]

[43]. Ceriello A, Lush CW, Darsow T, Piconi L, Corgnali M, Nanayakkara N, Frias JP, Maggs D (2008) Pramlintide reduced markers of oxidative stress in the postprandial period in patients with type 2 diabetes. Diabetes Metab Res Rev 24, 103-108. [PubMed: 17694505]

[44]. Ceriello A, Motz E (2004) Is oxidative stress the pathogenic mechanism underlying insulin resistance, diabetes, and cardiovascular disease? The common soil hypothesis revisited. Arterioscler Thromb Vasc Biol 24, 816-823. [PubMed: 14976002]

[45]. Vorhees CV, Williams MT (2006) Morris water maze: procedures for assessing spatial and related forms of learning and memory. Nat Protoc 1, 848-858. [PubMed: 17406317]

[46]. Head E, Pop V, Sarsoza F, Kayed R, Beckett TL, Studzinski CM, Tomic JL, Glabe CG, Murphy MP (2010) Amyloid-beta peptide and oligomers in the brain and cerebrospinal fluid of aged canines. J Alzheimers Dis 20, 637-646. [PubMed: 20164551]

[47]. Murphy MP, Morales J, Beckett TL, Astarita G, Piomelli D, Weidner A, Studzinski CM, Dowling AL, Wang X, Levine H 3rd, Kryscio RJ, Y Lin, Barrett E, Head E (2010) Changes in cognition and amyloid-beta processing with long term cholesterol reduction using atorvastatin in aged dogs. J Alzheimers Dis 22, 135-150. 
[48]. Cuende J, Moreno S, Bolanos JP, Almeida A (2008) Retinoic acid downregulates Rae1 leading to APC(Cdh1) activation and neuroblastoma SH-SY5Y differentiation. Oncogene 27, 3339-3344. [PubMed: 18212744]

[49]. Miloso M, Villa D, Crimi M, Galbiati S, Donzelli E, Nicolini G, Tredici G (2004) Retinoic acidinduced neuritogenesis of human neuroblastoma SH-SY5Y cells is ERK independent and PKC dependent. J Neurosci Res 75, 241-252. [PubMed: 14705145]

[50]. Wu X, Song Y, Li S, Liu X, Hua W, Wang K, Liu W, Li S, Zhang Y, Shao Z, Yang C (2018) Pramlintide regulation of extracellular matrix (ECM) and apoptosis through mitochondrialdependent pathways in human nucleus pulposus cells. Int J Immunopathol Pharmacol 31, 394632017747500. [PubMed: 29256292]

[51]. Zhang N, Yang S, Wang C, Zhang J, Huo L, Cheng Y, Wang C, Jia Z, Ren L, Kang L, Zhang W (2017) Multiple target of hAmylin on rat primary hippocampal neurons. Neuropharmacology 113, 241-251. [PubMed: 27743934]

[52]. Wang H, Joseph JA (1999) Quantifying cellular oxidative stress by dichlorofluorescein assay using microplate reader. Free Radic Biol Med 27, 612-616. [PubMed: 10490282]

[53]. Liebmann T, Renier N, Bettayeb K, Greengard P, Tessier-Lavigne M, Flajolet M (2016) Threedimensional study of Alzheimer's disease hallmarks using the iDISCO clearing method. Cell reports 16, 1138-1152. [PubMed: 27425620]

[54]. Oakley H, Cole SL, Logan S, Maus E, Shao P, Craft J, Guillozet-Bongaarts A, Ohno M, Disterhoft J, Van Eldik L, Berry R, Vassar R (2006) Intraneuronal beta-amyloid aggregates, neurodegeneration, and neuron loss in transgenic mice with five familial Alzheimer's disease mutations: potential factors in amyloid plaque formation. J Neurosci 26, 10129-10140. [PubMed: 17021169]

[55]. Santos RX, Correia SC, Zhu X, Smith MA, Moreira PI, Castellani RJ, Nunomura A, Perry G (2013) Mitochondrial DNA oxidative damage and repair in aging and Alzheimer's disease. Antioxid Redox Signal 18, 2444-2457. [PubMed: 23216311]

[56]. Smith MA, Nunomura A, Zhu X, Takeda A, Perry G (2000) Metabolic, metallic, and mitotic sources of oxidative stress in Alzheimer disease. Antioxid Redox Signal 2, 413-420. [PubMed: 11229355]

[57]. Smith MA, Perry G, Richey PL, Sayre LM, Anderson VE, Beal MF, Kowall N (1996) Oxidative damage in Alzheimer's. Nature 382, 120-121.

[58]. Swerdlow RH, Khan SM (2004) A “mitochondrial cascade hypothesis” for sporadic Alzheimer's disease. Med Hypotheses 63, 8-20. [PubMed: 15193340]

[59]. Tramutola A, Lanzillotta C, Perluigi M, Butterfield DA (2017) Oxidative stress, protein modification and Alzheimer disease. Brain Res Bull 133, 88-96. [PubMed: 27316747]

[60]. Moslemnezhad A, Mahjoub S, Moghadasi M (2016) Altered plasma marker of oxidative DNA damage and total antioxidant capacity in patients with Alzheimer's disease. Caspian J Intern Med 7, 88-92. [PubMed: 27386059]

[61]. Abdel Moneim AE (2015) Oxidant/Antioxidant Imbalance and the Risk of Alzheimer's Disease. Current Alzheimer Research 12, 335-349. [PubMed: 25817254]

[62]. Pan Y, Qiao QY, Pan LH, Zhou DC, Hu C, Gu HF, Fu SK, Liu XL, Jin HM (2015) Losartan reduces insulin resistance by inhibiting oxidative stress and enhancing insulin signaling transduction. Exp Clin Endocrinol Diabetes 123, 170-177. [PubMed: 25502581]

[63]. Paolisso G, D’Amore A, Volpe C, Balbi V, Saccomanno F, Galzerano D, Giugliano D, Varricchio M, D’Onofrio F (1994) Evidence for a relationship between oxidative stress and insulin action in non-insulin-dependent (type II) diabetic patients. Metabolism 43, 1426-1429. [PubMed: 7968598]

[64]. Pereira S, Park E, Mori Y, Haber CA, Han P, Uchida T, Stavar L, Oprescu AI, Koulajian K, Ivovic A, Yu Z, Li D, Bowman TA, Dewald J, El-Benna J, Brindley DN, Gutierrez-Juarez R, Lam TK, Najjar SM, McKay RA, Bhanot S, Fantus IG, Giacca A (2014) FFA-induced hepatic insulin resistance in vivo is mediated by PKCdelta, NADPH oxidase, and oxidative stress. Am J Physiol Endocrinol Metab 307, E34-46. [PubMed: 24824652]

[65]. Wittmann I, Nagy J (1996) Are insulin resistance and atherosclerosis the consequences of oxidative stress? Diabetologia 39, 1002-1003. [PubMed: 8858227] 
[66]. Verdile G, Keane KN, Cruzat VF, Medic S, Sabale M, Rowles J, Wijesekara N, Martins RN, Fraser PE, Newsholme P (2015) Inflammation and Oxidative Stress: The Molecular Connectivity between Insulin Resistance, Obesity, and Alzheimer's Disease. Mediators Inflamm 2015, 105828. [PubMed: 26693205]

[67]. Lontchi-Yimagou E, Sobngwi E, Matsha TE, Kengne AP (2013) Diabetes mellitus and inflammation. Curr Diab Rep 13, 435-444. [PubMed: 23494755]

[68]. David A, Kallay C, Sanna D, Lihi N, Sovago I, Varnagy K (2015) Potentiometric and spectroscopic studies on the copper(II) complexes of rat amylin fragments. The anchoring ability of specific non-coordinating side chains. Dalton Trans 44, 17091-17099. [PubMed: 26369733]

[69]. Joseph J, Janaki GB (2016) Copper complexes bearing 2-aminobenzothiazole derivatives as potential antioxidant: Synthesis, characterization. J Photochem Photobiol B 162, 86-92. [PubMed: 27344637]

[70]. Kupcewicz B, Sobiesiak K, Malinowska K, Koprowska K, Czyz M, Keppler B, Budzisz E (2013) Copper(II) complexes with derivatives of pyrazole as potential antioxidant enzyme mimics. Med Chem Res 22, 2395-2402. [PubMed: 23542890]

[71]. Smith MA, Kutty RK, Richey PL, Yan SD, Stern D, Chader GJ, Wiggert B, Petersen RB, Perry G (1994) Heme oxygenase-1 is associated with the neurofibrillary pathology of Alzheimer's disease. Am J Pathol 145, 42-47. [PubMed: 8030754]

[72]. Wegiel B, Nemeth Z, Correa-Costa M, Bulmer AC, Otterbein LE (2014) Heme oxygenase-1: a metabolic nike. Antioxid Redox Signal 20, 1709-1722. [PubMed: 24180257]

[73]. Dwyer BE, Nishimura RN, De Vellis J, Yoshida T (1992) Heme oxygenase is a heat shock protein and PEST protein in rat astroglial cells. Glia 5, 300-305. [PubMed: 1375192]

[74]. Stocker R (1990) Induction of haem oxygenase as a defence against oxidative stress. Free Radic Res Commun 9, 101-112. [PubMed: 2189794]

[75]. Hettiarachchi N, Dallas M, Al-Owais M, Griffiths H, Hooper N, Scragg J, Boyle J, Peers C (2014) Heme oxygenase-1 protects against Alzheimer's amyloid-beta(1-42)-induced toxicity via carbon monoxide production. Cell Death Dis 5, e1569. [PubMed: 25501830]

[76]. Schipper HM, Bennett DA, Liberman A, Bienias JL, Schneider JA, Kelly J, Arvanitakis Z (2006) Glial heme oxygenase-1 expression in Alzheimer disease and mild cognitive impairment. Neurobiol Aging 27, 252-261. [PubMed: 16399210]

[77]. Wang Y, Miao Y, Mir AZ, Cheng L, Wang L, Zhao L, Cui Q, Zhao W, Wang H (2016) Inhibition of beta-amyloid-induced neurotoxicity by pinocembrin through $\mathrm{Nrf} 2 / \mathrm{HO}-1$ pathway in $\mathrm{SH}-\mathrm{SY} 5 \mathrm{Y}$ cells. J Neurol Sci 368, 223-230. [PubMed: 27538638]

[78]. Clementi G, Caruso A, Maria Catena Cutuli V, Prato A, de Bernardis E, Erio Fiore C, AmicoRoxas M (1995) Anti-inflammatory activity of amylin and CGRP in different experimental models of inflammation. Life Sciences 57, PL193-PL197. [PubMed: 7564878]

[79]. Lee CY, Landreth GE (2010) The role of microglia in amyloid clearance from the AD brain. J Neural Transm (Vienna) 117, 949-960. [PubMed: 20552234]

[80]. Ansari MA, Scheff SW (2011) NADPH-oxidase activation and cognition in Alzheimer disease progression. Free Radic Biol Med 51, 171-178. [PubMed: 21457777]

[81]. Murakami K, Murata N, Noda Y, Irie K, Shirasawa T, Shimizu T (2012) Stimulation of the amyloidogenic pathway by cytoplasmic superoxide radicals in an Alzheimer's disease mouse model. Biosci Biotechnol Biochem 76, 1098-1103. [PubMed: 22790929]

[82]. Thu VT, Kim HK, Ha SH, Yoo JY, Park WS, Kim N, Oh GT, Han J (2010) Glutathione peroxidase 1 protects mitochondria against hypoxia/reoxygenation damage in mouse hearts. Pflugers Arch 460, 55-68. [PubMed: 20306076]

[83]. Beckhauser TF, Francis-Oliveira J, De Pasquale R (2016) Reactive Oxygen Species: Physiological and Physiopathological Effects on Synaptic Plasticity. J Exp Neurosci 10, 23-48. [PubMed: 27625575]

[84]. Swerdlow RH, Burns JM, Khan SM (2014) The Alzheimer's disease mitochondrial cascade hypothesis: progress and perspectives. Biochim Biophys Acta 1842, 1219-1231. [PubMed: 24071439] 
[85]. Kimura R, MacTavish D, Yang J, Westaway D, Jhamandas JH (2017) Pramlintide Antagonizes Beta Amyloid (Abeta)- and Human Amylin-Induced Depression of Hippocampal Long-Term Potentiation. Mol Neurobiol 54, 748-754. [PubMed: 26768593] 


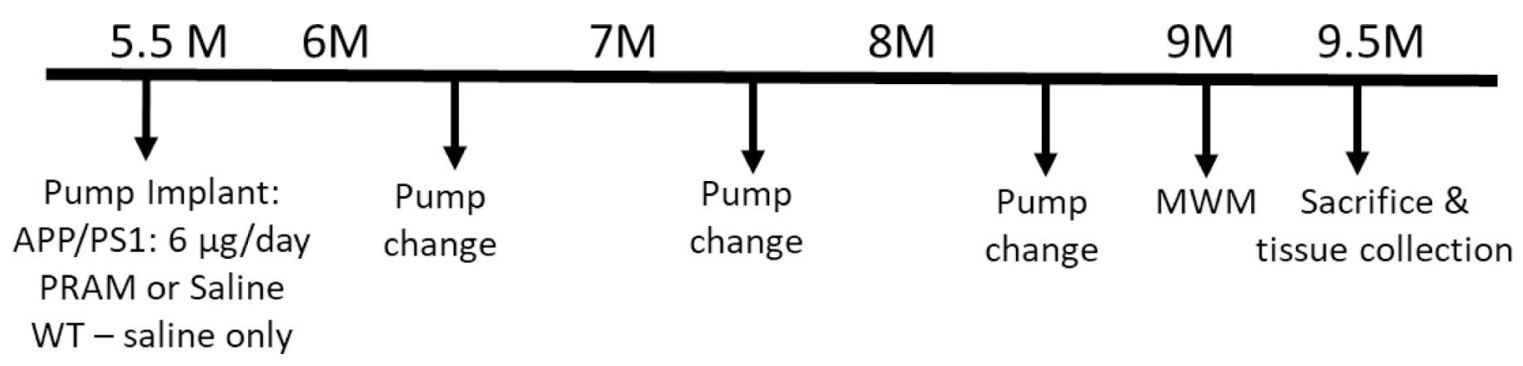

Figure 1. Experimental timeline for in vivo study.

Male $(n=15)$ and female $(n=15)$ APP/PS1 and their WT male $(n=13)$ and female $(n=12)$

littermates were aged until 5.5 mo. of age until a 6 week Alzet mini-osmotic pump was surgical implanted subcutaneously and replaced every 40 days 2 times. A week before sacrifice, mice were subjected to Morris Water Maze Swim task. 

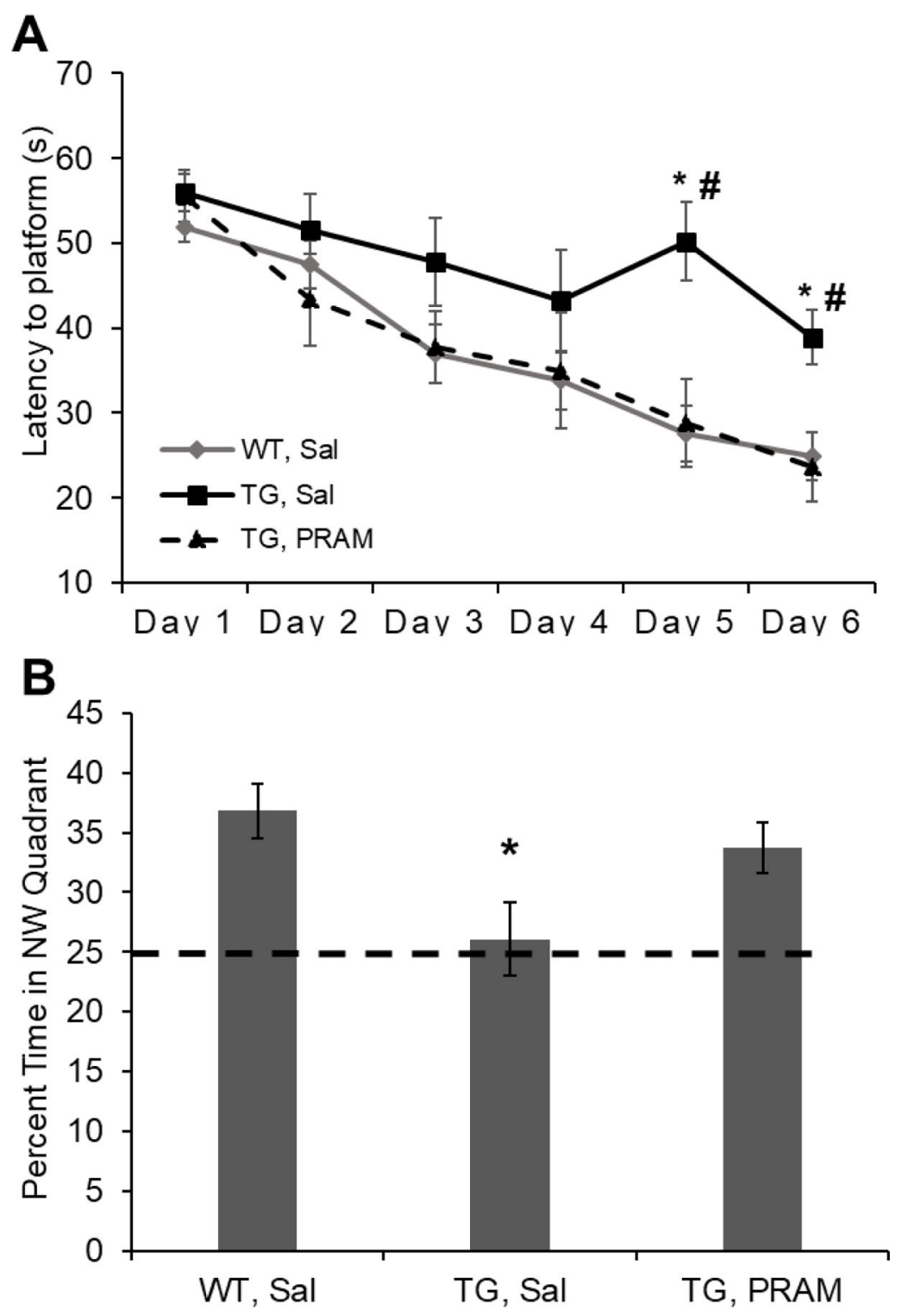

Figure 2. Pramlintide treatment improves AD-related Hippocampal dysfunction.

A. MWM training in wild-type (WT+Sal, n=21[11 females, 10 males]), saline treated APP/PS1 (Tg+Sal, $\mathrm{n}=14$ [6 females, 8 males] and pramlintide-treated APP/PS1 mice (Tg +PRAM, n=12 [4 females, 7 males]). B. Probe trial, \% time spent in target quadrant for WT $+\mathrm{SAL}, \mathrm{Tg}+\mathrm{Sal}$ and Tg+PRAM groups. Results depicted as mean \pm SEM. Significance: * $\mathrm{P}<0.05$ relative to $\mathrm{WT}$; $=\mathrm{P}<0.05$ relative to $\mathrm{Tg}+\mathrm{SAL}$. 

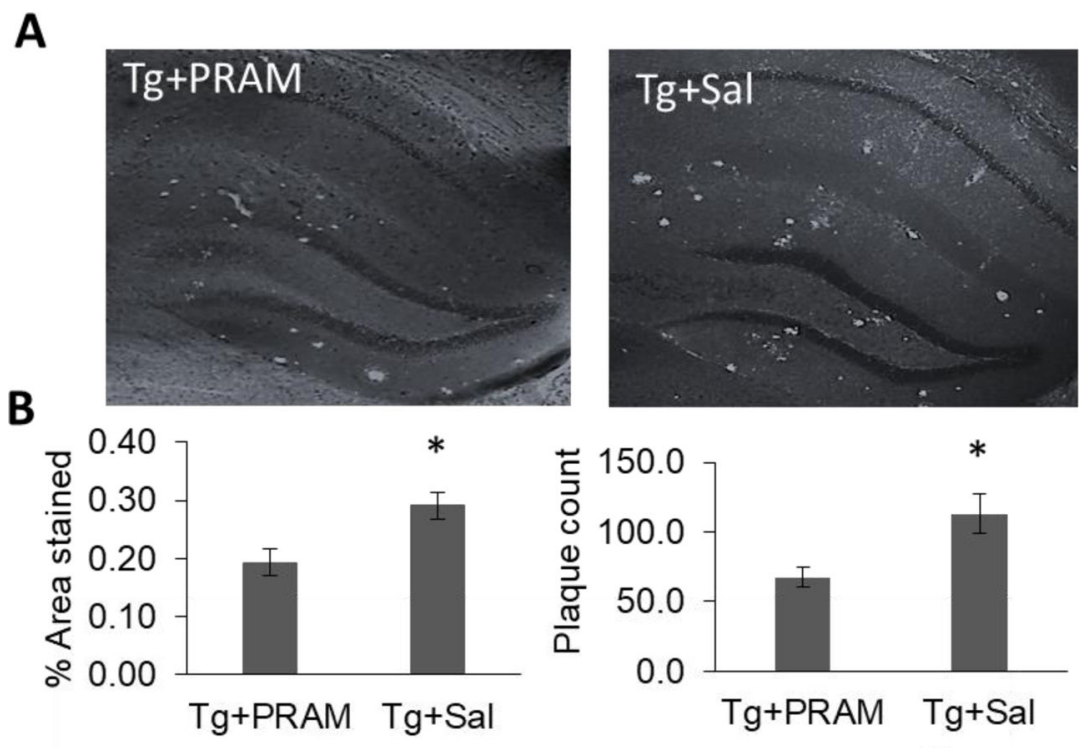

C

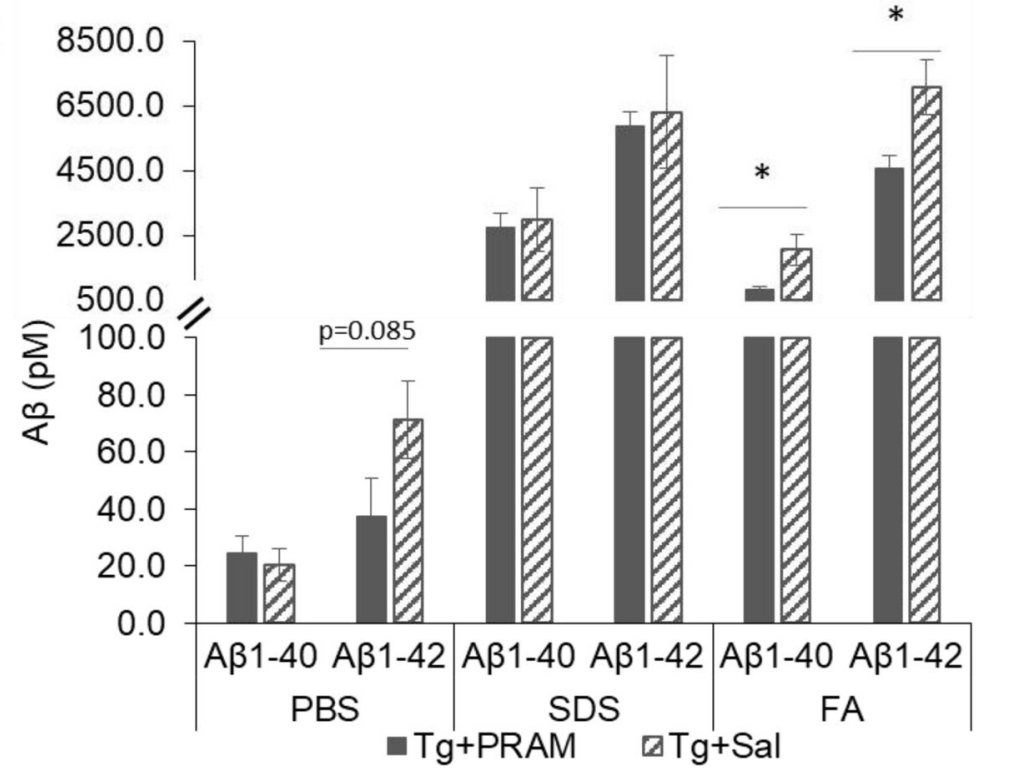

Figure 3. Pramlintide reduces soluble and insoluble A $\beta$ levels in the hippocampi of APP/PS1 mice.

A. Representative images of Thioflavin $S$ in the hippocampus of saline treated APP/PS1 mice (Tg+SAL, $\mathrm{n}=6$ [ 2 females, 4 males]) and PRAM treated APP/PS1 mice (Tg+PRAM, $\mathrm{n}=5$ [1 females, 4 males]). B. Quantification of $\%$ area stained and number of plaques (plaque count). C. Sandwitch ELISA for soluble (PBS), membrane bound (SDS) and insoluble [formic acid (FA)] levels of A $\beta 1-40$ and $A \beta 1-42$ in the hippocampus of saline treated $(\mathrm{Tg}+\mathrm{SAL}, \mathrm{n}=4$ (all males)) and PRAM treated (Tg+PRAM, $\mathrm{n}=4$ (all males)) APP/PS1 mice. Results depicted as mean \pm SEM. Significance: $*=\mathrm{P}<0.05$ relative to WT. 


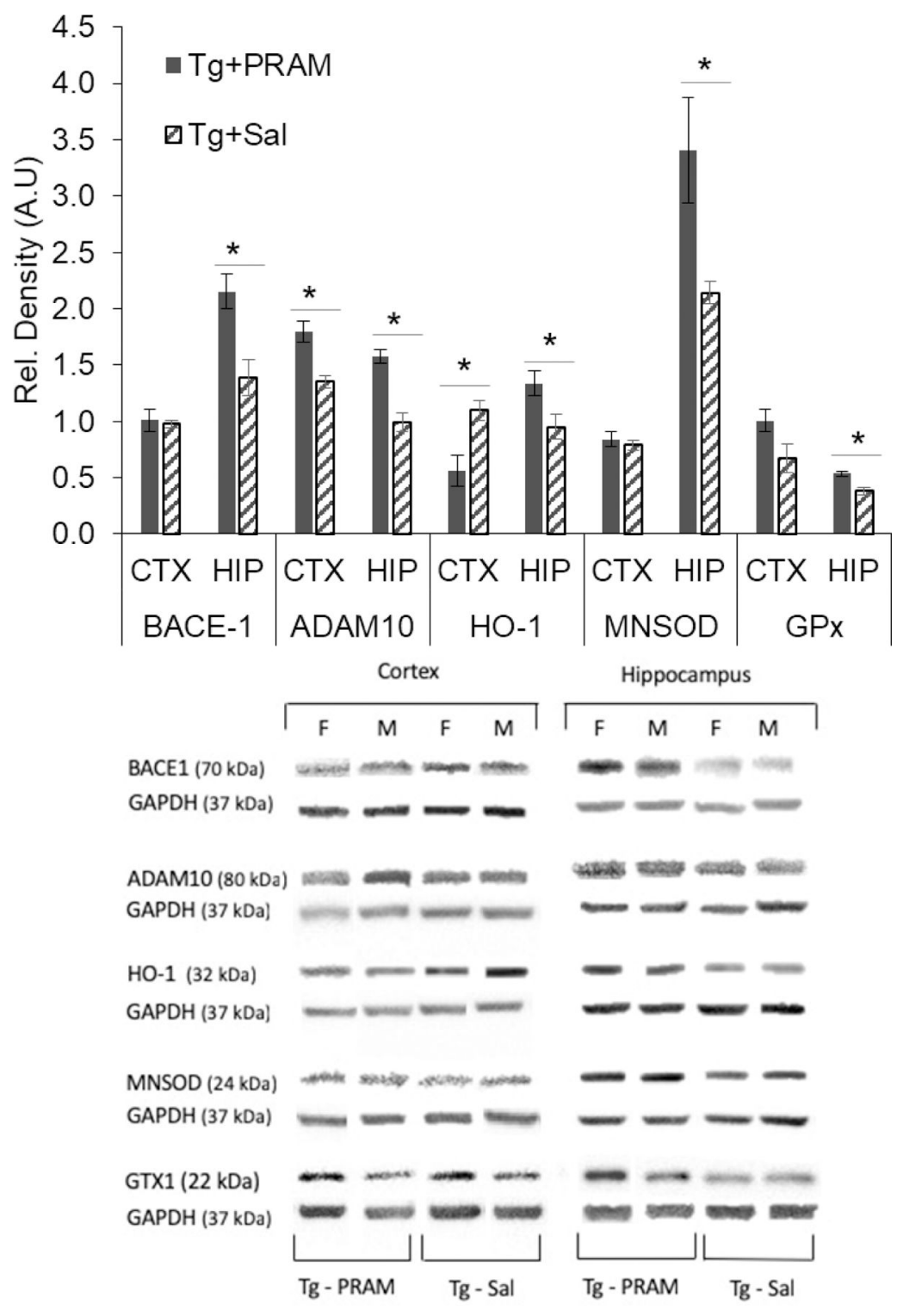

Figure 4. Pramlintide treatment regulates APP processing and oxidative stress in a region specific manner in APP/PS1 mice.

Western blot quantification of BACE1 ( $\beta$-secretase) and ADAM10 ( $a$-secretase) expression in cortex and hippocampus in saline treated APP/PS1 mice $(\mathrm{Tg}+\mathrm{SAL}, \mathrm{n}=6$ [3 females, 3 males]) and PRAM treated APP/PS1 mice (Tg+PRAM, n=5 [2 females, 3 males]). Western blot quantification of Heme-oxigenase 1 (HO-1) and MNSOD expression in cortex and hippocampus (Hip) in saline treated APP/PS1 mice (Tg+SAL, $\mathrm{n}=6$ [3 females, 3 males]) and PRAM treated APP/PS1 mice (Tg+PRAM, $n=5$ [2 females, 3 males]). Results depicted as mean $\pm \mathrm{SEM} *=\mathrm{P}<0.05$ relative to $\mathrm{WT} ; \#=\mathrm{P}<0.05$ relative to $\mathrm{Tg}+\mathrm{SAL}$. 

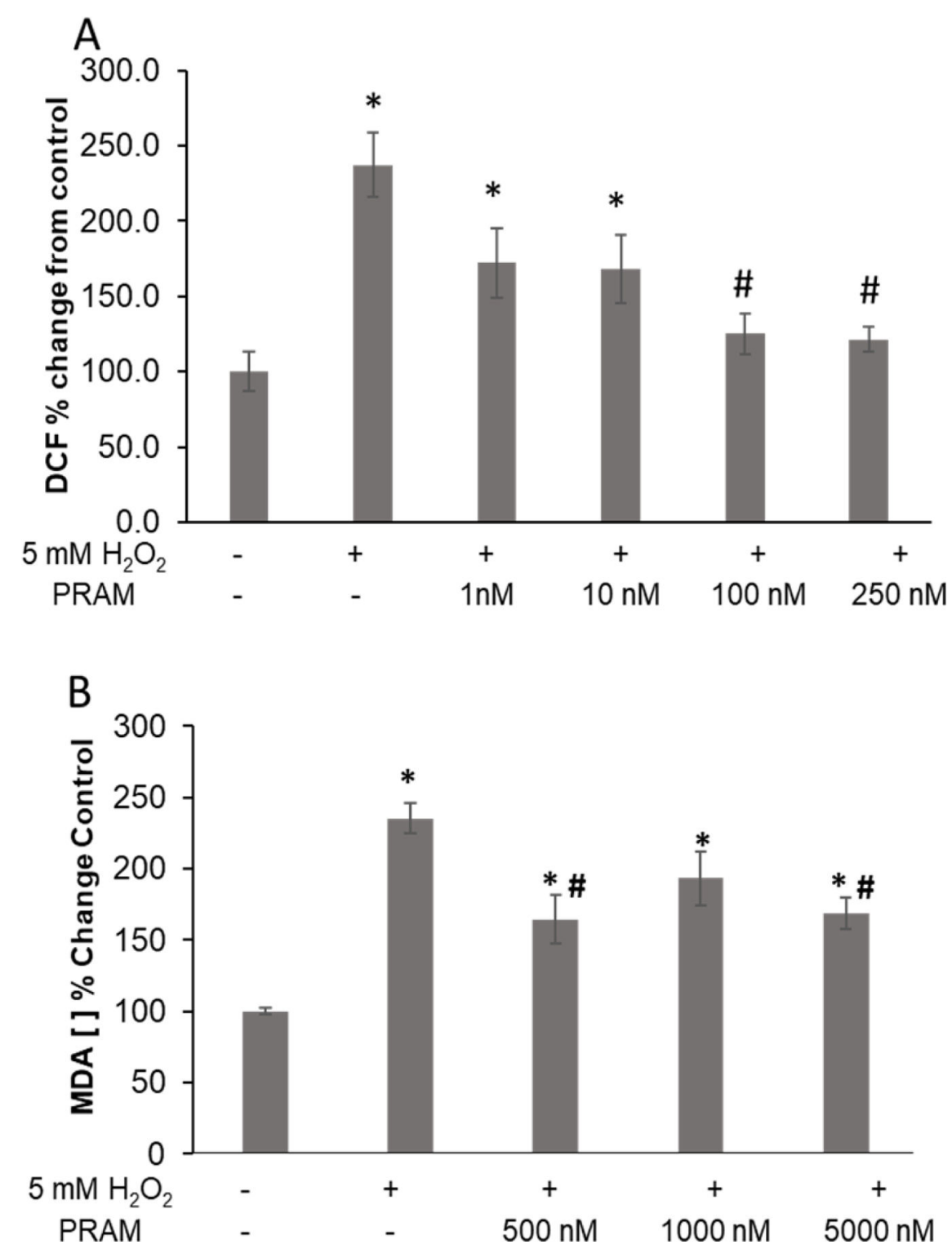

Figure 5. Pramlintide reduces $\mathrm{H} 2 \mathrm{O} 2$-mediated endogenous oxidative stress production and damage in differentiated SHSY5Y.

A. Change in relative DCF fluorescence. Doses: $\mathrm{H}_{2} \mathrm{O}_{2}$ alone and 1, 10, 100, \& $250 \mathrm{nM}$ PRAM $+\mathrm{H}_{2} \mathrm{O}_{2}$. Each treatment group was ran in $\mathrm{n}=6$ and the experiment was repeated 3 times. B. Change in MDA concentration. Doses: $\mathrm{H}_{2} \mathrm{O}_{2}$ alone and 500, 1000, \& $5000 \mathrm{nM}$ PRAM $+\mathrm{H}_{2} \mathrm{O}_{2}$. Results depicted as percent change from untreated control as mean $\pm \mathrm{SEM}$. $*=\mathrm{p}<0.05$, relative to untreated control; $\#=\mathrm{p}<0.05$, relative to $\mathrm{H}_{2} \mathrm{O}_{2}$ alone. The treatment groups were ran in triplicate and repeated 3 times. 